\title{
A Human Rights View of Maritime Piracy Law: Exploring the Gulf of Guinea
}

\author{
Ramat Tobi Abudu* \\ Keywords: \\ DOI: $10.21827 /$ GroJIL.9.1.1-22 \\ UNCLOS; HUMAN RIGHTS LAW; GULF OF GUINEA; NIGERIA; PIRACY LAW
}

\begin{abstract}
As a result of pirates' unique modus operandi in the Gulf of Guinea (GoG), the current approach to counter-piracy is mainly securitised and repressive. This approach follows the international provisions on piracy framed based on the customary international law categorising pirates as "enemy of mankind"; which, considering the vicious nature of the crime, is quite justified. Moreover, the increase in piracy activities at sea within the GoG is foreseeable considering the economic recession faced by countries within the region due to the Covid-19 pandemic. This prediction calls for the strengthening of law enforcement operations at sea, which must be justifiable in international human rights law in order to ensure the protection of all persons. Thus, reviewing the current piracy laws and their coherence with international human rights law is a requisite. This paper recognises the repressive counter-piracy approach's success, but takes a glance from a human rights lens, which raises questions relating to "lawfulness". Consequently, this paper builds on the existing literature criticising the repressive policy towards countering piracy in the GoG. It also advances the research probing the alignment of counter-piracy operations with human rights obligations. This paper additionally takes it a step further by evaluating the piracy laws in the GoG and their alignment with human rights provisions. These findings set a new course towards a more sustainable approach to countering piracy in the GoG, balancing rights and security approaches towards ensuring the protection of lives at sea.
\end{abstract}

\section{Introduction}

There is a well-founded fear that the aftermath of the Covid-19 pandemic will welcome more vicious pirate attacks due to global and national economic recession. ${ }^{1}$ Although global piracy has plummeted since 2018 due to the current proactive international counterpiracy operations carried out by both states and organisations, there are still concerns for the sustainability of the existing legal and operational measures. The initial epicentre for piracy was the Horn of Africa and the Gulf of Aden, which was overrun by Somali-based pirates, but currently, that area records no cases of piracy. The present epicentre is the Gulf of Guinea (GoG). While it has always been infiltrated by Nigerian pirates, the cases in the GoG have persistently increased in the last five years. The current modus operandi of pirates in the GoG differs from that in the Gulf of Aden. Therefore, there is a need to investigate the region's specificity in addressing the crime of piracy. It is, however, beyond the scope of this paper to consider all the areas infiltrated by pirates.

In this paper, international piracy law refers to the United Nations Convention on Law of the Sea (UNCLOS) and the Convention for the Suppression of Unlawful Acts

1 Brandon Prins, 'Piracy is on the rise, and coronavirus could make it worse' (World Economic Forum, 15 May 2020) <https://www.weforum.org/agenda/2020/05/global-sea-piracy-coronavirus-covid19/> accessed 18 July 2021.

This work is licensed under the Creative Commons Attribution-NonCommercial-NoDerivatives 4.0 International License. To view a copy of this license, visit http://creativecommons.org/licenses/by-nc-nd/4.0/. 
Against the Safety of Maritime Navigation (SUA Convention). ${ }^{2}$ National and regional piracy laws replicate the international level provisions with a few differences, reflected in this paper. Using the GoG as a case study, this paper evaluates the questionable aspects of the current regional and domestic anti-piracy law for their non-alignment with international human rights law standards. Considering that these regional and domestic laws depict international provisions, this paper argues that the problem exists ab initio from international law and questions these provisions.

In outlining the above submission, after briefly reviewing the nature of piracy in the GoG, this article analyses the current regional and domestic legal framework on piracy in the GOG. The next section of the paper first argues that the nature of the maritime environment influences how courts interpret human rights law and law enforcement operations at sea. Yet, there are still gaps in consideration of these operations, which regardless violates the right to liberty. Subsequently, the section evaluates piracy and human rights law from the victims' perspective (seafarers, crew members and masters of the ship), the suspects (the arrested pirates) and the state with a general evaluation of the global requirement. This part of the paper mostly makes reference to the European Court of Human Rights (ECtHR) cases because of the Court's progressive jurisprudence in interpreting human rights law at sea compared to other courts.

After the above section, the author discusses the reality of building a sustainable approach to piracy at sea. A strategy that focuses on protecting all human lives at sea through human rights law and security-based policies. It is beyond the scope of this paper to provide a framework for sustainable counter-piracy policy and operation. However, the author offers a blueprint from pre-existing materials. Consequently, the conclusion gives an overview of the findings by recounting three questions in the paper and ultimately suggests further research to build this much-needed sustainable approach to countering piracy at sea.

\section{Case Study: Gulf of Guinea}

The Gulf of Guinea (GoG) is part of the Atlantic Ocean off the western African coast and is considered the Earth's geographic centre. ${ }^{3}$ The GoG includes both oil-producing and potentially oil-producing states along the coast of West Africa, Central Africa and Southern Africa. Therefore, piracy in the GoG poses a threat to global energy security. The region encompasses over a dozen countries, namely Angola, Benin, Cameroon, Central African Republic, Côte d'Ivoire, Democratic Republic of the Congo (DRC), Equatorial Guinea, Gabon, The Gambia, Ghana, Guinea, Guinea-Bissau, Liberia, Nigeria, Republic of the Congo (Congo-Brazzaville), São Tomé and Príncipe, Senegal, Sierra Leone and Togo.

The International Maritime Bureau's Piracy Reporting Centre (IMB PRC) records an increase in global piracy. In 2020, the IMB recorded 195 incidents of piracy and armed robbery against ships, compared to 162 incidents in $2019.4^{4}$ This rise is attributed to

2 United Nations Convention on the Law of the Sea (adopted 10 December 1982, entered into force 16 November 1984) 1833 UNTS 3 (UNCLOS); See also Convention for the Suppression of Unlawful Acts Against the Safety of Maritime Navigation (adopted 10 March 1988, entered into force 1 March 1992) 1678 UNTS 222 (SUA Convention).

3 Kennedy Mbekeani and Mthuli Ncube, 'Economic Impact of Maritime Piracy' (2011) 2(10) African Development Bank, <http://www.afdb.org/fileadmin/uploads/afdb/Documents/Publications/Maritime\%20Piracy_Marit ime\%20Piracy.pdf $>$ accessed 18 July 2021.

4 ICC International Maritime Bureau, 'Piracy and Armed Robbery Against Ships' (Report, January 2021) <https://www.icc-ccs.org/reports/2020_Annual_Piracy_Report.pdf> accessed 18 July 2021. 
increased piracy and armed robbery in the GoG, accounting for $95 \%$ of the crew members kidnapped globally. ${ }^{5}$ Conversely, no Somalia-based piracy cases were recorded in 2020, but the threat of events still exists in the Southern Red Sea and Gulf of Aden's waters, including Yemen. Aside from the increase in piracy in West Africa, there was also an increase in piratical activities in Southeast Asia, and 2020 saw a significant rise in kidnappings in the Singapore Strait. ${ }^{6}$

GoG piracy is not the traditional paradigm of Somalia-based piracy; it is a hybrid of conventional and insurgent piracy. Although Somali pirates operated with considerable skill and resolve, aided by sophisticated criminal networking, their modus operandi still fits into the paradigm of traditional piracy. ${ }^{7}$ In this context, the pirates hijack a ship and require a ransom payment negotiated for the ship's release. East Africa's piracy crisis has ceased due to a combination of international, national and privately contracted security personnel, including reforms to the regional judicial system. ${ }^{8}$ The GoG presents a different scenario, with its hybrid of traditional and insurgent piracy. Unlike Somalia, pirates in West Africa frequently disable a ship's equipment and take control of the ship - this model requires combating piracy and other consequently related crimes. ${ }^{9}$ Instead, Somali pirates concentrate on kidnapping for ransom, capturing vessels and controlling their cargo and crew to extort money from their shipowners.

The GoG pirates launch attacks primarily from Nigeria to steal cargo, equipment or valuables from a vessel and its crew. ${ }^{10}$ The kidnapping of crew members happens, albeit rarer than in the Indian Ocean. Yet, the levels of violence are high because the GoG pirates are less concerned with maintaining the wellbeing of hostages. ${ }^{11}$ The causal factors contributing to piracy in the GoG are: "legal and jurisdictional weakness, favourable geography, conflict and disorder, underfunded law enforcement, inadequate security, permissive political environments, cultural acceptability, and promise of reward". ${ }^{12}$ The key drivers of piracy are poverty, unemployment, lack of economic opportunities, environmental conditions and political corruption. Other drivers are the domestic conflicts and border disputes between GoG countries that fuel piratical activities in the GoG. For instance, some Nigerian pirates relate to the separatist Movement for the Emancipation of the Niger Delta (MEND). Although the Federal Government gave amnesty to the MEND group, they rebelled for politically motivated reasons, and it is unclear if it comes within the treaty definition of piracy. ${ }^{13}$ Still, their violence against foreign-flagged vessels mimicked piracy attacks. A border dispute on the Bakassi Peninsula between Cameroon

ibid.

ibid.

Kamal-Deen Ali, 'Anti-Piracy Responses in the Gulf of Guinea: Addressing the Legal Deficit' in Carlos Esposito et al (eds), Ocean Law and Policy : Twenty Years of Development Under the UNCLOS Regime (Brill Nijhoff 2016) 211.

8 ibid.

9 ibid.

10 ibid 213.

11 ibid 211.

12 Eero Tepp, 'The Gulf of Guinea: Military and Non-Military Ways of Combatting Piracy Baltic Security and Defence' (2012) 14 Baltic Security and Defence 181, 182.

13 UNCLOS (n 2) art 101(a) provides that piracy is "any illegal acts of violence or detention, or any act of depredation, committed for private ends by the crew or the passengers of a private ship or a private aircraft." The wording for 'private ends' is disputed within the international community: it is unclear if this includes political motivations or not; See Arron N Honniball, 'Private Political Activists and The International Law Definition of Piracy: Acting for 'Private Ends' (2015) 36 Adelaide Law Review 279, 279-328; Honniball argues that private ends includes private politically motivated crimes that involves violence. 
and Nigeria led to large areas of their maritime borders being under-governed, allowing a haven to develop for pirate groups.

Piracy in GoG is a "symptom of a deeper malaise" but also a disease itself. ${ }^{14}$ Yet, both the root causes and the security concern posed by piracy must be dealt with simultaneously to ensure a sustainable solution building upon peace, justice and strong institutions. The reality is that these root causes prevalent in developing countries turn people towards piracy, while weak law enforcement and corruption allow piracy to flourish in the GoG. Therefore, there must be a balanced solution to piracy - including in the GoGwhich involves an all hands-on deck approach. There are various bilateral, regional, national and extra-regional regimes to combat piracy and armed robbery at sea in the GoG; nonetheless, they are only repressive. Nigeria is the only country in the GoG with an antipiracy law. However, other countries have some security-focused rules embedded in their criminal codes. This gap in legislation affects the effective prosecution of the offence of piracy within the GoG and, in turn, affects the effectiveness of counter-piracy operations.

Nevertheless, the current legal regime in maintaining security in the GoG ranges from hard law to soft law. The only binding African Union regime is the African Charter on Maritime Security and Safety and Development in Africa (Lomé Charter). ${ }^{15}$ The other is a soft law document titled Code of Conduct Concerning the Repression of Piracy, Armed Robbery against Ships, and Illicit Maritime Activity in West and Central Africa (Yaoundé Code of Conduct) specifically for the GoG. ${ }^{16}$ There are also several international operational initiatives to combat piracy in the GoG. In 2013, the international community established the G7++ Friends of the Gulf of Guinea (G7++ FOGG), with the G7 states together with Belgium, Denmark, the Netherlands, Norway, Portugal, Spain, Switzerland (and Brazil as an observer) and international bodies (the European Union (EU), the United Nations Office on Drugs and Crime and Interpol) as members of the initiative. The G7++FOGG initiated co-operation with the oil and shipping industry and Economic Community of Central African States (ECCAS) and Economic Community of West African States (ECOWAS) to support the Yaoundé Code of Conduct implementation. Another initiative is the reporting mechanism operated by the French and UK navies called the Maritime Domain Awareness for Trade in the GoG (MDAT-GoG). This mechanism allows shipmasters to report their presence in the GoG and report any occurring incident to signal a warning to other ships. In 2016, the EU launched the GoG Inter-Regional Network (GoGIN), covering 19 GoG states, aimed at improving maritime security in the GoG, mainly by establishing an effective and technically efficient regional informationsharing network.

In 2020, the plummet in the national economy of most West African states due to the coronavirus pandemic presented the potential for increased pirate activities in the

14 Freedom Onuoha 'Piracy and Maritime Security in the Gulf of Guinea: Trends, Concerns, and Propositions' (2013) 4 The Journal of the Middle East and Africa 267, 270-74; See also Paul Williams and Lowry Pressly, 'Maritime Piracy: A Sustainable Global Solution' (2013) 46 Case Western Reserve Journal of International Law 177, 184.

15 African Union regime is the African Charter on Maritime Security and Safety and Development in Africa (Lomé Charter) (adopted October 15, 2016) < https://au.int/sites/default/files/treaties/37286-treatyafrican_charter_on_maritime_security.pdf $>$ accessed 1 September 2021.

16 Code of Conduct Concerning the Repression of Piracy, Armed Robbery against Ships, and Illicit Maritime Activity in West and Central Africa (adopted March 13, 2013) (Hereinafter referred to as "The Yaoundé Code of Conduct) <https://wwwcdn.imo.org/localresources/en/OurWork/Security/Documents/code_of_conduct\%20si gned\%20from\%20ECOWAS\%20site.pdf accessed 1 September 2021. 
GoG. ${ }^{17}$ The real fear is whether the current legal and operational framework is sufficient to combat the predicted increase in piratical activities. Currently, several GoG states are adjusting their national budget. Pigeon and Moss argue that if Nigeria's budget constraints curtail the "government's ability to sustain its demobilisation and reintegration programs for former combatants in the Delta, history suggests piracy and armed robbery may rise". ${ }^{18}$ Besides, regional and international co-operation in the GoG might be affected considerably given the pandemic's impact on nations. For example, in March 2020, the Italian Navy stepped in for a French naval mission deployed to the GoG to support regional counterpiracy operations after it was recalled to France. ${ }^{19}$ Although the volunteer action by the Italian Navy is commendable, it might not be sustainable for all states in the long run, considering the global economic impact of the coronavirus pandemic. ${ }^{20}$

\section{Regional Anti-Piracy Law: Yaoundé Code of Conduct}

The United Nations Security Council (UNSC) adopted Resolutions 2018 and 2039 in October 2011 and February 2012 respectively. ${ }^{21}$ This, among other things, encouraged states of the ECOWAS, the ECCAS and the Gulf of Guinea Commission (GGC) to fashion a comprehensive strategy through the development of domestic laws and regulations, where these are not in place, criminalising piracy and armed robbery at sea; the development of a regional framework to counter piracy and armed robbery at sea, and the development and strengthening of domestic laws and regulations, as appropriate, to implement relevant international agreements addressing the safety and security of navigation, in accordance with international law. ${ }^{22}$

After adopting these resolutions, ECOWAS, ECCAS and GGC member-states convened the Cotonou Joint Ministerial Conference on Maritime Security in the Gulf of Guinea held in March 2013 to draft a regional strategy. The Cotonou conference participants set a summit in Yaoundé Cameroon for the 24th and 25th of June in 2013. The summit with the theme of Maritime Security in the GoG brought together twenty-five countries from the GoG to formalise the adoption of an integrated response to a comprehensive security challenge in the region. The majority endorsed the documents drafted during the Cotonou Conference at the Yaoundé Summit, known as the Yaoundé Code of Conduct Concerning the Repression of Piracy, Armed Robbery against Ships, and Illicit Maritime Activity in West and Central Africa, otherwise known as the Yaoundé Code of Conduct of June 2013. ${ }^{23}$

The Yaoundé Code of Conduct is a non-legally binding document aimed at addressing piracy, armed robbery against ships, illegal fishing and other illicit maritime activity in the area. This document came out of the need to step up the continent's strategic approach towards maritime safety and security. Moreover, it is part of the increasing

17 Maisie Pigeon and Kelly Moss, 'Why Piracy Is a Growing Threat in West Africa's Gulf of Guinea' (World Politics Review, 9 June 2020) <https://www.worldpoliticsreview.com/articles/28824/in-west-africa-sgulf-of-guinea-piracy-is-a-growing-threat> accessed 18 July 2021.

18 ibid.

19 Martin Manaranche, 'Italian Navy Deploys Frigate to The Gulf of Guinea While French Navy Suspends Patrol Mission' (Naval News, March 29 2020). <https://www.navalnews.com/navalnews/2020/04/italian-navy-deploys-frigate-to-the-gulf-of-guinea-while-french-navy-suspends-patrolmission/> accessed 18 July 2021.

20 Pigeon and Moss (n 17).

21 See UNSC Res 2018(2011) (31 October 2011) UN Doc S/Res/2018(2011). See also UNSC Res 2039(2012) (29 February 2012) UN Doc S/Res/2039(2012).

22 The Yaoundé Code of Conduct (n 16) Preamble, Recital 2.

${ }^{23}$ Ken Ifesinachi and Chikodiri Nwangwu, 'Implementation of the Yaoundé Code of Conduct and Maritime Insecurity in the Gulf of Guinea' (2015) 5 Research on Humanities and Social Sciences 54, 57. 
commitment of African leaders to express political will and set the leadership tone in the governance of Africa's maritime domain. Accordingly, Article 2 (1) (a) of the Code of Conduct states that the Signatories intend to fully cooperate in the repression of transnational organised crime in the maritime domain, maritime terrorism, IUU fishing and other illegal activities at sea.

Compared to the SUA Convention, ${ }^{24}$ the Yaounde Code of Conduct explicitly provides that measures taken according to Code should be carried out by law enforcement or other authorised warships or military aircrafts. ${ }^{25}$ Therefore, unlike the SUA Convention, the Code of Conduct applies to warships. Furthermore, Article 1(3) of the Code of Conduct reiterates piracy under Article 101 UNCLOS, while Article 1(4) defines armed robbery at sea following the International Maritime Organization (IMO)'s definition. Accordingly, it reiterates the geographical limitation of the piracy definition under UNCLOS, including the private ends and two ships requirements, ${ }^{26}$ which some consider a gap problem affecting the prosecution of pirates. ${ }^{27}$ But these gaps are supplemented by laws to prosecute other offences such as armed robbery at sea.

The main provisions dealing with piracy and armed robbery at sea are Articles 6 and 7. Article 6 requires full cooperation between the member states in carrying out enforcement and adjudicatory functions such as arresting, seizure of pirate ships, investigating and prosecuting persons who have committed piracy or are reasonably suspected of committing piracy. However, a profound requirement omitted in the SUA Convention but included in the Yaoundé Code of Conduct is that member states cooperate to rescue ships, persons, and property subject to piracy. ${ }^{28}$ This provision recognises that pirate attacks induce distress and gives rise to the duty to assist persons or vessels in distress (Article 98 UNCLOS). An occurrence of distress means the existence of a risk to life. ${ }^{29}$ The protection of the right to life is fundamental to the enjoyment of all other human rights, which informs other human rights.

Nonetheless, international law does not recognise the right to life as a corresponding right to the duty to assist persons in distress at sea. Trevisanut argues that the right to be rescued at sea is the corresponding right derived from the positive obligation on states to protect life.$^{30}$ From a sceptical point, Papastavridis agrees with Trevisanut's view only to the extent that it applies within the normative framework of human rights law and cannot be transposed into the law of the sea (as a matter of lex lata) ${ }^{31}$ Accordingly, the right to be rescued at sea cannot find its basis in the law of the sea- as it is mainly focused only on the state's duty rather than the right of persons in distress. Also, the protection of such rights requires an individual and state-oriented redress system like the human rights courts and other monitoring and enforcement mechanisms, unlike the solely state-oriented redress mechanism under the law of the sea.

24 SUA Convention (n 2).

25 The Yaoundé Code of Conduct (n 16) art 3.

26 See United Nation Conference on Trade and Development (UNCTAD), 'Maritime Piracy: An overview of the International Legal Framework and of Multilateral Cooperation to Combat Piracy' (2014) 2 Studies in Transport Law and Policy.

27 Waseem Ahmad Qureshi, 'The Prosecution of Pirates and the Enforcement of Counter-Piracy Laws Are Virtually Incapacitated by Law Itself' (2017) 19 San Diego International Law Journal, 95.

28 The Yaoundé Code of Conduct (n 16) art 6(1)(c).

29 Yoshifumi Tanaka, 'Key Elements in International Law Governing Places of Refuge for Ships: Protection of Human Life, State Interests, And Marine Environment' (2014) 45 Journal of Maritime Law and Commerce 157, 160

30 Saline Trevisanut, 'Is there a right to be rescued at sea? A constructive view' (2014) 4 Questions of International Law $3,7$.

31 Efythimous Papastavridis, 'Is there a right to be rescued at Sea? A skeptical view' (2014) 4 Questions of International Law 17, 20. 
Article 6(4) the Code points out that consistent with international law, the signatory's courts that carry out a seizure may decide upon the penalties to be imposed and may also determine the action to be taken against the ship or property. However, the issue is that international law does not prescribe the content of national criminal proceedings for piracy, i.e., penalties and actions against piracy. Criminalisation is subject to national laws of the state deciding the piracy case, which ranges from fines/imprisonment, life sentences and the death penalty. Consequently, transferring or delivering a piracy suspect to another adjudicating state with strict sentencing such as a death penalty/life imprisonment can raise human rights concerns.

The Code of Conduct focuses on developing and promoting training and educational programmes to maintain safety and order at sea to repress piracy. ${ }^{32}$ At the national level, the Code of Conduct requires states to develop and implement national maritime security policies, committees and plans to safeguard and enhance maritime transport from all unlawful acts. ${ }^{33}$ Following the Yaoundé Code of Conduct, the signatories created maritime safety and security architecture in the GoG (Yaoundé Architecture). The Yaoundé Architecture comprises the Interregional Coordination Centre (ICC), the coordination and information-sharing structure that connects the Regional Maritime Security Centre for Central Africa (CRESMAC) and the Regional Maritime Security Centre for West Africa (CRESMAO).

Underneath the regional CRESMAC and CRESMAO levels, the maritime security architecture in the GoG is made up of five operational maritime zones $(A ; D ; E ; F ; G)$ covering the ECOWAS and ECCAS maritime space, each co-ordinated by a Maritime Multinational Coordination Centre (MMCC). The various zones and their coastal states are Zone A (Angola, Congo DRC), Zone D (Cameroon Equatorial Guinea, Gabon, Sao Tome \& Principe), Zone E (Benin, Niger, Nigeria, and Togo), Zone F (Ghana, Burkina Faso, Guinea, Côte d'Ivoire, Liberia and Sierra Leone), Zone G (Cabo Verde, Gambia, Guinea-Bissau, Mali, and Senegal). At the national level, Maritime Operational Centres (MOC) envisaged in each country gather the main stakeholders connected to states action at sea (maritime police, customs, fisheries and environment protection) and the national navies in charge of the coordination.

The Yaoundé Code of Conduct has a repressive approach towards piracy in the GoG, which has led to securitisation measures by the Signatories to the document. These securitisation measures are "cross border and regional naval acquisitions, international naval training and assistance programmes, increased naval interventions in pirate attacks, heightened naval patrols and vessel security measures, employment of local armed security, use of extra-watch duty, reinforcement of ships self-defence and use of citadel safe rooms." ${ }^{34}$ However, the securitised approach is not optimal and, therefore, incapable of addressing a sustainable basis - states carry out such measures without equal consideration of the coastal communities' socio-economic development. ${ }^{35}$ Thus, the reason why this "repressive approach has been implicated in the rising spate of these illegal maritime activities" in the GoG. ${ }^{36}$

32 The Yaoundé Code of conduct (n 16) art 14.

33 The Yaoundé Code of Conduct (n 16) art 4.

34 Ifesinachi and Nwangwu (n 23) 63.

35 ibid, 63; See also Ramat Tobi Abudu, 'Global Human Security: A Cornerstone in Bridging the Divide Between Securitisation and The Human Rights Maritime Security Framework' (2020) 4 Edinburgh Student Law Review 27.

36 Ifesinachi and Nwangwu (n 23) 63. 


\section{Domestic Anti-Piracy Law: The case of Nigeria}

The oil development influences maritime piracy in Nigeria, and the resulting economic, social, and environmental conditions in the Niger Delta. ${ }^{37}$ Nigeria is the first and currently the only country as of 2020 in the GoG region to pass a standalone anti-piracy law. Nigeria's Suppression of Piracy and Other Maritime Offences Act 2019 (POMO Act) aims to prevent and suppress piracy, armed robbery, and any other unlawful act against a ship, aircraft including fixed and floating platforms. It also gives effect to UNCLOS and the SUA Convention and its Protocol. The POMO Act's strengths are, among others, its definition of piracy, which is in line with UNCLOS, and its specific punishments for violations.

One main challenge with the POMO Act is its lack of clarity on the various security agencies' roles and responsibilities in dealing with piracy. Section 17(1) and (2) of the POMO Act mandates the Nigerian Maritime Administration and Safety Agency (NIMASA) to coordinate all maritime activities and security, including "to prevent and combat piracy, maritime offences and any other unlawful acts prohibited by this Act". Even though the Armed Forces Act of 1993 makes Nigeria's Navy responsible for enforcing safety in Nigerian waters, including the Exclusive Economic Zone (EEZ) - The POMO Act makes no mention of NIMASA and the Navy's relationship. ${ }^{38}$ Furthermore, NIMASA is not the only authorised agency. Section 17(3) of the POMO Act provides that the law enforcement and security agencies be responsible for gathering intelligence, patrolling waters, and investigating offences. Unfortunately, the POMO Act does not provide which law enforcement agencies are responsible for the functions under Section 17(3). Accordingly, the Institute for Security Studies points out that "oversight may deepen inter-agency rivalry", and thus affecting the national co-operation to deal with piracy in the GoG. ${ }^{39}$ Nonetheless, the Nigerian government designed a Harmonised Standard Operating Procedures on arrest, detention, and prosecution of vessels and persons in Nigeria's maritime environment (HSOP) to guide the operation of maritime law enforcement agencies and adequately address the overlap of responsibilities between various agencies.

Furthermore, the POMO Act operates independently of other land-based domestic laws that influence piracy at sea. This includes laws governing firearms, kidnapping and money laundering. Usually, piracy proceeds are connected to illicit financial activities and document fraud; therefore, it is crucial to deal with related crimes. ${ }^{40}$ Also, as an organised crime, piracy is linked to the trafficking of guns, illicit drugs, trafficking and smuggling of people and fuel smuggling. Yet, the POMO Act does not address the procurement of pirates' weapons, the recruitment of pirates, and those who provide pirates with safehavens. In Kenya, for instance, the anti-piracy law covers other related crimes like money laundering and organised crime. ${ }^{41}$

The POMO Act's final challenge is that it did not reference the Yaoundé Code of Conduct, which is the only viable document - albeit not legally binding - that enables cooperation to deal with piracy in the GoG. The inclusion of the Yaoundé Code in the

37 Tepp (n 12) 186.

38 The Armed Forces Act $\quad$ Section 1993 1(4) <https://www.ecoi.net/en/file/local/1041285/4765_1465378595_armed-forces-act.pdf> accessed 18 July 2021.

39 See Maurice Ogbonnaya, 'Nigeria's anti-piracy law misses the mark' (Institute for Security Studies, 7 May 2020) available at <https://issafrica.org/iss-today/nigerias-anti-piracy-law-misses-the-mark> accessed 18 July 2021.

40 ibid.

41 The Merchant Shipping Act (2009) arts 369 and 371. 
POMO Act would have strengthened the document's effectiveness and transitioned it from soft law into hard law. The omission of the Yaoundé Code of Conduct which supports regional co-operation signifies Nigeria's stance in counter-piracy cooperation in the GoG.

\section{Private Maritime Security Contractor}

Private maritime security onboard foreign vessels largely contributed to reducing piracy attacks in the Gulf of Aden (including the Somali territorial waters).$^{42}$ Unfortunately, most West African states prohibit the use of private security within their territorial waters. Nigeria has taken a particularly aggressive stance against any use of private security; going so far as to apprehend ships making use of private security within their EEZ. ${ }^{43}$ As a result, the only legal options available to shipping companies seeking to bolster their defences are security companies sanctioned by the state or national forces such as the navy or marine police. ${ }^{44}$ Such limitation makes transiting external private armed security personnel through the GoG almost impossible, increasing the risk of pirate attacks. As discussed further below, the growing international standard and practice of using private security personnel might presumably influence the stance in the GoG. Currently, various soft law regimes govern this thriving practice.

There are some non-legally binding guidelines to regulate the use of force by private security personnel in their defence against pirates. ${ }^{45} \mathrm{IMO}$ points out that the use of privately contracted maritime security personnel onboard a merchant ship or fishing vessel is a matter for the flag state to determine in consultation with shipowners, operators and companies. ${ }^{46}$ All legal requirements of flag, port and coastal states should be met before the private armed contactor(s) boards the ship. ${ }^{47}$ Also, the UN Firearms Protocol, a legally binding agreement that entered into force in 2005, contains clauses that allow states to authorise the movement of firearms through their domestic legislation. ${ }^{48}$ Through the UN Firearms Protocol, states can transit privately armed security providers or Military Vessel Protection Details (VPDs) to protect commercial vessels.

However, the role of private armed security appears to be limited to defending persons/cargo and not the arrest of pirates or the seizure of their ships. Article 107

42 Gregory DeAngelo and Taylor Leland Smith 'Private security, maritime piracy and the provision of international public safety' (2020) 60 Journal of Risk and Uncertainty 77, 77-97.

43 The Armed Forces Act (n 38) Section 1(4).

44 Kyle Best, 'The Development of Piracy Law in West Africa \& the Institutions Underpinning CounterPiracy Efforts' (2015) 3(10) International Human Rights Internships Working Paper Series, 7 <ihri_wps_v3n10-kyle_best.pdf(mcgill.ca)> accessed 31 August 2021.

45 'Interim Guidance to private maritime security companies providing contracted armed security personnel on board ships in High-Risk Area' (International Maritime Organisation) <https://www.imo.org/en/OurWork/Security/Pages/Private-Armed-Security.aspx> accessed 18 July 2021; See 100 Series Rules: An international Model Set of Maritime Rules for the Use of Force <https://www.humanrightsatsea.org/wp-content/uploads/2015/04/20130503-

100_Series_Rules_for_the_Use_of_Force.pdf $>$ accessed 18 July 2021; See also BIMCO, 'Guidance on Rules for the Use of Force by Privately Contracted Armed Security Personnel (PCASP) in Defence of Merchant Vessel (MV0)' <https://www.bimco.org/-/media/bimco/contracts-andclauses/contracts/guidance/guidance-on-rules-for-the-use-of-force-ruf-2016-09.ashx> accessed 18 July 2021.

46 IMO, 'Piracy and Armed Robbery against Ships: Guidance to shipowners and ship operators, shipmasters and crews on preventing and suppressing acts of piracy and armed robbery against ships' (2019) MSC.1/Circ.1334, para 63 (use of privately contracted armed security personnel).

47 ibid.

48 Protocol Against the Illicit Manufacturing of and Trafficking in Firearms, Their Parts and Components and Ammunition, Supplementing the United Nations Convention against Transnational Organized Crime (adopted 31 May 2001, entered into force 3 July 2005) 2362 UNTS 208 art 3(e). 
UNCLOS provides that "seizure on account of piracy may be carried out only by warships or military craft or vessels clearly marked and identifiable as being on government service and authorised to that effect". Accordingly, under Articles 101 and 107, private security guards could be classified as suspected pirates if they took on the role of arresting pirates or seizing their ships. ${ }^{49}$ Yet, it is unclear if this limitation extends to military personnel contracted as private security officials.

There is no international treaty on the immunity of the VPDs from prosecution by a third state, albeit the Arbitral Tribunal in the Enrica Lexie case has set a precedent on the immunity of military VPDs at sea. ${ }^{50}$ Therefore, they are not subject to any other state's criminal or civil law. However, the private armed guards are not immune from criminal or civil liability. The immunity of VPDs might influence their acceptance as security guards of vessels transiting high-risk areas that constitute states' territorial seas/EEZ.

\section{International Human Rights Law}

International human rights law applies during the arrest, detention, transfer or delivery of piracy suspects. ${ }^{51}$ Suspected pirates are entitled to humane treatment, consisting of the absence of arbitrary detention, the right to be brought promptly before a judge, the right to a fair trial, freedom from transfer/delivery to a country that will apply the death penalty and conflict with fundamental human rights. Also, the seafarers, crew members and master of a ship are entitled to the right to life which creates an obligation on states to protect, respect and fulfil the right to life of persons within their jurisdiction. Furthermore, Article 98 UNCLOS recognises states' duty to assist persons in distress at sea. The duty of the coastal state is to "promote the establishment, operation and maintenance of an adequate and effective search and rescue service regarding safety on and over the sea and, where circumstances so require, by way of mutual regional arrangements cooperate with neighbouring states for this purpose". ${ }^{52}$ One can construe the phrase "search and rescue services regarding safety on and over the sea" to apply to deal with piracy activities - that is, state coordinated operations to rescue seafarers and crew members of an attacked ship. Although this is an unexamined deduction, it is plausible because of the implicit link between Article 98 UNCLOS and the right to life, considering its primary object and purpose is to protect human lives at sea.

The presence of competing jurisdictions in anti-piracy operations also means various human rights law instruments are at play. Concerning counterpiracy activities at the GoG, the human rights instruments discussed below are the International Covenant on Civil and Political Rights (ICCPR), ${ }^{53}$ the European Convention on Human Rights

49 Patrick Cullen and Claude Berube, Maritime Private Security: Market Responses to Piracy, Terrorism and Waterborne Security Risks in the 21st Century (Taylor \& Francis Group 2012).

50 See Enrica Lexie Case (The Italian Republic v the Republic of India) (PCA Award) [2016] ICGJ 550 where two Italian marines providing government authorised Vessel Protection Detail (VPD) onboard the Italian tanker Enrica Lexie shot and killed two Indian fishermen. The two marines were subsequently arrested and detained by the Indian authorities. The Permanent Court of Arbitration (PCA) in the 2020 Award para 1094 decided that "Marines are entitled to immunity in relation to the acts that they committed during the incident of 15 February 2012, and that India is precluded from exercising its jurisdiction over the Marines." <https://pcacases.com/web/sendAttach/13647> accessed 1 September 2021.

51 Anna Petrig, Human Rights and Law Enforcement at Sea: Arrest, Detention and Transfer of Piracy Suspects (Brill 2014) 157.

52 UNCLOS (n 2) art 98(2).

53 International Covenant on Civil and Political Rights (adopted 16 December 1966, entered into force 23 March 1976) 999 UNTS 171. 
(ECHR) ${ }^{54}$ and the African Charter on Human and Peoples Rights (ACHPR). ${ }^{55}$ The discussion below looks at three perspectives: the suspected pirates, the victims and the state.

\section{A. Maritime Enforcement Operations and Suspected Pirate's Right to liberty and security}

Usually, the friction between human rights law and maritime enforcement operations flags concerns over state violations of human rights law. The problem emanates from interpreting the procedural rights and safeguards under the human rights framework and law enforcement operations at sea-specifically, the right to liberty and security.

The right to liberty and security is a fundamental right enshrined in various human rights instruments, national constitutions and domestic legislation. ${ }^{56}$ This right entails the right to be brought promptly before a judge. For example, Article 5(3) ECHR provides that:

Everyone arrested or detained in accordance with the provisions of paragraph 1(c) of this Article shall be brought promptly before a judge or other officer authorised by law to exercise judicial power and shall be entitled to trial within a reasonable time or to a release pending trial. ${ }^{57}$

The interpretation of the phrase "brought promptly before a judge" is beset with uncertainties when applied in the maritime context and is often violated by states during maritime law enforcement operations. For example, in Ali Samatar and Others v. France, ${ }^{58}$ a dozen men armed with assault rifles and rocket launchers seized a cruise ship flying the French flag and took its crew hostage. ${ }^{59}$ In reaction to this, the French Government obtained the consent of the Somali Transitional Federal Government (TFG) to enter into Somali territorial waters to take all necessary measures - including appropriate use of force. ${ }^{60}$ The French Navy placed the applicants under their control before being put on a French military aircraft on 15th April, around 3 p.m. The plane landed in France on 16th April 2008, and the suspects were arraigned on 18th April 2008. The French Court held in favour of the French Government. However, the ECtHR overturned the judgment and held that the two days detention violated Article 5(3) ECHR. The Court ordered the release of the applicants, and the French Government had to pay damages. ${ }^{61}$

A similar situation happened in Hassan and Others $v$. France. ${ }^{62}$ In this case, the ECHR unanimously held that there was a breach of Article 5(3), considering that the suspects were brought before a judge six days and sixteen hours after their detention in a Djibouti

54 Convention for the Protection of Human Rights and Fundamental Freedoms (adopted 4 November 1950, entered into force 3 September 1953) 213 UNTS 231.

55 African Charter on Human and Peoples Rights (adopted 27 June 1981, entered into force 21 October 1986) 1520 UNTS 217.

56 See Universal Declaration of Human Rights (adopted 10 December 1948) UNGA Res 217 A(III) (UDHR) art 3; See also ICCPR (n 53) art 9; See also ECHR (n 54) art 5.

57 ECHR (n 54) art 5(3).

58 Ali Samatar and Others v France App no 17110/10 and 17301/10 (ECtHR, 04 December 2014).

59 ibid.

60 ibid.

61 ibid.

62 Hassan and Others v France App no 46695/10 and 54588/10 (ECtHR, 04 December 2014). 
military base and subsequent transfer to France. Accordingly, the Court ordered the French Government to pay damages to the applicants. ${ }^{63}$

In Rigopoulos $v$ Spain ${ }^{64}$ and Medvedyev $v$ France, ${ }^{65}$ ships flying the Panamanian and the Cambodian flags, respectively, were intercepted on the high seas. In the Rigopoulos case, the Spanish Navy intercepted the Panamanian ship, while in the Medvedyev case, the Cambodian flagship was intercepted by the French Navy on suspicion of drug trafficking. In both cases, the Navy found vast quantities of drugs on board, some thrown overboard by the crew members. The crew members were taken into custody on the Navy ship, brought to a port of the arresting state, and later submitted to criminal proceedings. The time spent between boarding and arraignment before a judge was 16 days in the Rigopoulos case and 13 days in the Medvedyev case. In both cases, the crew members claimed that the state detaining them had violated Article 5(1) and Article 5(3) of the ECHR. ${ }^{66}$

In the above cases, the Court held a violation of Article 5(1) ECHR. In Rigopoulos v Spain, the Court stated that "the applicant was undoubtedly deprived of his liberty, since he was detained on a vessel belonging to the Spanish customs and that detention lasted for sixteen days." ${ }^{67}$ In Medvedyev $v$ France, the Court stated that:

While it is true that the applicants' movements prior to the boarding of the Winner were already confined to the physical boundaries of the ship, so that there was a de facto restriction on their freedom to come and go, it cannot be said, as the Government submitted, that the measures taken after the ship was boarded merely placed a restriction on their freedom of movement. The crew members were placed under the control of the French special forces and confined to their cabins during the voyage. True, the Government maintained that during the voyage, the restrictions were relaxed. In the Court's view that does not alter the fact that the applicants were deprived of their liberty throughout the voyage as the ship's course was imposed by the French forces. ${ }^{68}$

However, in the above cases, the Court also held that there was no violation of Article 5(3) ECHR because it recognised in Rigopoulous and Medvedyev that only "exceptional circumstances" could justify such prolonged detention. ${ }^{69}$ Therefore, the Court noted in the Medvedyev judgment that "it was materially impossible to bring the applicant "physically" before such authority any sooner." 70

These cases demonstrate the relevance of the maritime environment in interpreting human rights. Nonetheless, these cases also highlight the possible challenges in harmonising human rights considerations with maritime law enforcement operations. ${ }^{71} \mathrm{In}$ Medvedyev, there are two parts of the dissenting opinion of the judges. In the first part: 7 out of the 17 judges jointly expressed the dissenting opinion that there was no violation of

63 ibid.

64 Rigopoulos v Spain App no 37388/97 (ECtHR, 12 January 1999).

65 Medvedyev v France App no 3394/03 (ECtHR, 29 March 2010).

66 ECHR (n 54) art 5(1) provides "everyone has the right to liberty and security of person. No one shall be deprived of his liberty save in the following cases and in accordance with a procedure prescribed by law."

67 Rigopoulos $v$ Spain (n 64) para 9.

68 Medvedyev v France (n 65) paras 74-75.

69 ibid.

70 ibid para 67.

71 Brian Wilson, 'Human Rights and Maritime Law Enforcement' (2016) 52 Stanford Journal of International Law 243, 246. 
Article 5(1) ECHR as there was a legal basis for the suspects' detention. ${ }^{72}$ Article 5(1) (c) ECHR provides the legal basis for suspects' detention to bring them before the competent legal authority. But most of the Grand Chamber judges in Medvedyev held that the detained suspects' restriction on the arresting ship constituted a deprivation of liberty. ${ }^{73}$

In the second part: 8 out of 17 judges jointly expressed the dissenting opinion that there was a violation of Article 5(3) ECHR as "wholly exceptional circumstances" should not justify the unnecessary abridgement of fundamental human rights. ${ }^{74}$ The main issue was that the phrase "wholly exceptional circumstances", similarly used in the Rigopoulous case, was too vague to form the basis for an exception. Moreover, this dissenting opinion did not recognise the maritime environment's nature as key in interpreting human rights at sea. Conversely, the remaining nine judges held a majority view: there was no violation of Article 5(3) ECHR.

In Vassis and others $v$. France, the issue was whether France violated the requirement of Article 5(3) ECHR based on the 18-day transit to the port and the following 48 hours upon arrival at the port. The French government submitted it was "materially impossible to physically bring the applicants before the judicial authority any more promptly", and upon arrival at the port, the delay was due to the "number of persons concerned and the need for interpreters for the different acts and steps in the proceedings." 75 The ECtHR held that the 18-day transit was not more than necessary. However, the 48 hours delay upon arrival was not justifiable. Based on this judgment, Wilson points out that the Vassis case creates a balance between human rights and maritime law enforcement because the Court took cognisance of the marine environment's nature. ${ }^{76}$

However, all these cases lay out how maritime enforcement operations can lead to a violation of Article 5(1) ECHR, the right to liberty- even though there is no violation of Article 5(3) ECHR. ${ }^{77}$ In Medvedyev, even though the Government maintained that during the voyage, the restrictions on the suspects were relaxed, the Court found that "it does not alter the fact that the applicants were deprived of their liberty throughout the voyage as the ship's course was imposed by the French forces." 78 Similarly, in Rigopoulous, the Court held that the applicant was undoubtedly deprived of his liberty since he was detained on a vessel belonging to the Spanish customs and that detention lasted for sixteen days. ${ }^{79}$ The former case was detention during a voyage to be brought before a judge, and the latter was detention upon a non-moving/subsequently moving vessel. In both cases, the detention was a problem.

The above raises a question concerning the arrest of the suspected pirates and their detention onboard a law enforcement vessel. Deprivation of liberty under the ECHR entails the spatial, coercion and time elements: when a state agent detains a piracy suspect on board a law enforcement vessel (spatial component), the suspect has no free will to leave

72 Medvedyev v France (n 65) joint partly dissenting opinion of Judges Costa, Casadevall, Bîrsan, Garlicki, Hajiyev, Šikuta and Nicolaou.

73 ibid paras 74-75.

74 ibid, joint partly dissenting opinion of Judges Tulkens, Bonello, Zupančič, Fura, Spielmann, Tsotsoria, Power and Poalelungi paras 5-7, expresses the view that the Medvedyev case is different from the Rigopoulos case as the circumstances of the case are different, as the delay explains the reason for the delay and does not justify it.

75 Vassis and others $v$ France App no 62736/09 (ECHR, 27 June 2013).

76 Wilson (n 71) 267.

77 Jim Murdoch and Ralph Roche, The European Convention on Human Rights and Policing: A Handbook for Police Officers and other Law Enforcement Officials (Council of Europe Publishing 2013), 48.

78 Medveyev v France (n 65) para 74.

79 Rigopoulos $v$ Spain (n 64) para 8. 
the ship (coercion element) ${ }^{80}$ or when such a suspect is not brought promptly before the judge (time element). ${ }^{81}$ Yet, it is not clear whether the existence of one element triggers deprivation of liberty, as seen in Medvedyev. State enforcement agents exercise a form of coercion to arrest the suspected pirates and detain the individuals to be brought before a judge onshore. Therefore, such operations might easily flout human rights requirements according to any or all the elements discussed. This deduction is not conclusive, seeing as the evaluation of deprivation is on a case-by-case basis. It only raises concerns over how best such operations can fulfil the procedural lawfulness of the right to liberty.

\section{B. Arrest, Detention and Transfer of Piracy Suspect}

Warships (the navy) or law enforcement vessels marked to conduct maritime enforcement operations carry out the arrest, detention and transfer of piracy suspects. Since piracy is a crime, criminal procedural laws are presumably applicable except otherwise provided in the individual states. For example, states in the GoG, such as Nigeria, have an administration of criminal justice laws (criminal procedural laws) that apply to the military. However, the criminal procedure law of countries like Denmark and Germany does not apply to their military. ${ }^{82}$ Accordingly, such states participating in counter-piracy operations are not bound by their domestic criminal procedural laws. Although Criminal procedural law dictates the requirements for lawful deprivation of liberty such as arrest and detention, it is unclear if piracy laws meet such requirements under IHRL.

Article 105 UNCLOS gives all states the power to seize a pirate ship and arrest piracy suspects. Therefore, Article 105 UNCLOS provides a universal arrest warrant, although it is not clear if it fulfils the lawfulness of arrest for such counter-piracy operation. Article 107 UNCLOS gives the naval warships the power to conduct seizures on account of piracy, including the ability to board a vessel reasonably suspected of engaging in piracy. ${ }^{83}$ Although reading all these provisions outlines the substantive lawfulness of the arrest, procedural legality is still needed as contained under human rights law. This need was the contention in Medvedyev and others $v$ France where the Grand Chamber pointed out that none of the legal provisions relied on by the French Government afforded sufficient protection against the arbitrary violations of the right to liberty. The reasoning behind this was that "none of those provisions referred specifically to depriving the crew of the intercepted ship of their liberty or regulated the conditions of deprivation of liberty on board the ship." 84 This case relates to illegal drug trafficking, of which there is no universal jurisdiction compared to piracy at sea - thus, it arguably does not apply to counter-piracy operations. Though Article 105 of UNCLOS and various UNSC resolutions provide the legal authority to detain suspected pirates ${ }^{85}$ the lawfulness criteria relates to the "quality of the law" from an ECHR perspective. ${ }^{86}$ According to the ECtHR, this includes "the existence of clear legal provisions for ordering detention, for extending detention, and for setting time limits for detention; and the existence of an effective remedy by which the

80 Petrig (n 51) 157-165.

81 ibid 160-66; The concept of the time element is not settled but also regarded as relevant under the ECHR.

82 ibid 220-221.

83 UNCLOS (n 2) art 110.

84 Medvedyev v France (n 65) para 41.

85 Alice Priddy \& Stuart Casey-Maslen, 'Counterpiracy under International Law' (Geneva Academy of International Humanitarian Law and Human Rights 2012) 34; The authors mention that "Article 105 of the LOS Convention, Article 19 of the High Seas Convention, and various UN Security Council resolutions provide the legal authority to detain suspected pirates."

86 JN v The United Kingdom App No 37289/12 (ECtHR, 19 May 2016) para 77. 
applicant can contest the lawfulness and length of his continuing detention". ${ }^{87}$ As a framework, UNCLOS does not state all these, but national laws or the operations' mandate should meet the criteria. Also, national laws authorising deprivation of liberty must be sufficiently accessible, precise and foreseeable in their application; otherwise, they are arbitrary. ${ }^{88}$ Other components of the right to liberty and security under human rights law are the right to be informed at the time of arrest of the reasons for arrest; the right of detainees to be brought promptly before a judge or other judicial officers; and the right to be tried within a reasonable time.

Apart from aligning national piracy laws with human rights law, the counter-piracy operation's mandate must also align. An example is the notable EU Naval Force (EU NAVFOR) Somalia framework - Operation Atalanta (OA), the current military operation at sea conducted by the EU off the Horn of Africa and the Western Indian Ocean. The EU NAVFOR operation plan and the Council Joint Action (CJA) Operation Atalanta contains the OA's arrest and detention mandate- however, it is a non-public document. ${ }^{89}$ Therefore, Petrig concluded that based on expert interviews, the CJA OA did not meet the lawfulness standard of Article 5 (1) of the ECHR and 9 (1) of the ICCPR. ${ }^{90}$ Furthermore, as per the definition of transfer under Article 12 CJA OA regarding the detention and transfer of piracy suspects, persons "arrested and detained with a view of prosecution shall be transferred". ${ }^{91}$ The wording "shall be transferred" implies that the suspects can be detained with a transfer in view but does not outline the procedural requirement for such detention. ${ }^{92}$ Therefore, the legal basis for the lawfulness of a piracy detention pending transfer cannot be the CJA OA.

Even the Yaoundé Code of Conduct and the POMO Act addressing piracy in the GoG does not include provisions on the deprivation of liberty of piracy suspects. However, the HSOP, which coordinates maritime law enforcement in the Nigerian maritime domain and the GoG, has a human rights policy co-ordinating the arrest and detention of suspects. Paragraph 3 of the HSOP references the "procedural guarantees for investigation and prosecution", which includes "the right to be heard, the right to be informed of available remedies, the right of review by a competent authority, the right to representation by a legal practitioner of their choice, right to bail, and the right to appeal to a higher authority." 93 This provision appears to be a sufficient procedural basis in the context of "detention pending prosecution", looking at the deprivation of liberty in line with Article 9 ICCPR or Article 6 of the ACHPR. However, there is no mention of detention pending transfer of the suspect to a third country (the receiving state) - neither is there any mention of transfer proceedings. Moreover, the HSOP seems insufficient to provide such a justifiable basis as it is merely a "tool for administrative convenience". ${ }^{94}$

87 ibid.

88 ibid, para 77; See Nasrulloyev v Russia App No 656/06 (ECtHR, 11 October 2007), para 71; See also Khudoyorov v Russia App No 6847/02 (ECtHR, 11 July 2005) para 125.

89 Petrig (n 51) 230.

90 ibid 233.

91 ibid.

92 ibid.

93 'Harmonized Standard Operating Procedures (HSOP) on Arrest, Detention and Prosecution of Vessels and Persons in Nigeria's Maritime Environment 2016' (January 2017) <https://www.naptip.gov.ng/wpcontent/uploads/2017/05/Harmonized-SOP-on-Arrest-Detention-Prosecution-of-Vessels-Persons-inNigerias-Maritime-Environment-2016-1.pdf> accessed 19 July 2021.

94 Emeka Akabogu, Nigeria: Ship Detention Gone Rogue: A Critique of The "HSOP" For Ship Arrest And Detention (Mondaq, 22 February 2018) <https://www.mondaq.com/nigeria/marineshipping/675910/ship-detention-gone-rogue-a-critique-of-the-hsop-for-ship-arrest-and-detention> accessed 19 July 2021. 
Ultimately, the legal basis for the deprivation of liberty under the UNCLOS and SUA Convention does not meet the procedural requirements of lawful deprivation of liberty under the ICCPR, ECHR and ACHPR. However, due to piracy's dualistic nature, the international piracy law provides only the structure, while the national laws are the substantive/procedural legal basis for such arrest, detention and transfer. But some domestic legislation like the POMO Act does not provide for the detention pending transfer of piracy suspects to third states.

\section{The Principle of Non-refoulement- Exception to Transfer, Delivery or Extradition of Piracy Suspects}

The principle of non-refoulement prohibits removing a person to a state or territory where there are risks of facing torture, inhuman and degrading treatment. ${ }^{95}$ Whether or not the reasonably expected risk of human rights violation occurs is irrelevant to this obligation on states. ${ }^{96}$ Under international human rights law, neither the ICCPR, ACHPR nor the ECHR explicitly articulates this principle of non-refoulement. But the right to life and the prohibition of torture and other ill-treatment is often expanded to cover the non-refoulement obligation. ${ }^{97}$ The scope and content of the non-refoulement duty in the human rights context are expressed as follows:

No person shall be rejected, returned, or expelled in any manner whatever, where this would compel him or her to remain in or return to a territory where substantial grounds can be shown for believing that he or she would face a real risk of being subjected to torture or cruel, inhuman or degrading treatment or punishment. This principle allows for no limitation or exception. ${ }^{98}$

Additionally, Article 3 of the Convention against Torture and Other Cruel, Inhuman, or Degrading Treatment or Punishment (CAT) provides that no state party shall "expel, return, or extradite a person to another state where there are substantial grounds for believing that he would be in danger of being subjected to torture". ${ }^{99}$ This non-refoulement obligation applies irrespective of the offence a person has committed, i.e., no derogation is permitted - even for piracy suspects. ${ }^{100}$

In counter-piracy operations, the non-refoulement provisions apply extraterritorially based on the flag state principle (de jure jurisdiction) and when a suspect is on board a vessel in view of a decision to transfer or deliver him/her to a third state (de facto jurisdiction). ${ }^{101}$ Hirsi Jamaa $v$ Italy explains the scope of the non-refoulement obligation under the ECHR. In that case, the Court held that the Italian government's interception of migrants and immediately transferring them to Libya following a Memorandum of understanding (MOU) between both countries without assessing individual cases was a violation of the convention. ${ }^{102}$ This case shows that individual assessment of each case is necessary before any form of transfer. Relating this to piracy cases, the validity of an

95 Kees Wouters, International Legal Standards for the Protection from Refoulement (Intersentia 2009) 25.

96 ibid.

97 ICCPR (n 53) arts 6 and 7; See also ECHR (n 54) arts 2 and 3; See also ACHPR (n 55) arts 4 and 5.

98 Elihu Lauterpacht and Daniel Bethlehem, 'The scope and content of the principle of non-refoulement: Opinion' in Erika Feller et al (eds), Refugee Protection in International Law: UNHCR's Global Consultations on International Protection (Cambridge University Press 2003) 163.

99 Convention Against Torture and Other Cruel, Inhuman or Degrading Treatment or Punishment (Adopted and opened for signature 10 December 1984, entered into force 26 June 1987) 1465 UNTS 85 (CAT).

100 Petrig (n 51) 321-29.

101 ibid 326; See also Hirsi Jamaa and others v Italy App No 27765/09 (ECtHR, 23 February 2012).

102 Hirsi Jamaa and others $v$ Italy (n 101) paras 110-138. 
immediate transfer decision is questionable, even if there is an existing MOU between those countries. Furthermore, the death penalty raises several serious human rights concerns and can be regarded as inhumane and degrading punishment. Although Article 6 (2) of the ICCPR allow for an exception for the death penalty in construing the right to life recognised by Article 3 of the 1948 Universal Declaration of Human Rights (UDHR), the death penalty should be only applied for the most severe crimes.

The extent of the application of the above instruments varies. On the one hand, the CAT does not apply to "surrender for prosecution" cases, ${ }^{103}$ while the ICCPR and the ECHR do. On the other hand, even if the transfer is for prosecution, the transferring state must conduct a risk assessment of the detention center/ prison following the trial. ${ }^{104}$ Also, looking at the ECtHR case law and recommendations from the Human Rights Committee (HRC), the transfer of piracy suspects by an ECHR state party to a country that punishes piracy with a death penalty or the risk of torture, ill-treatment etc., may be questionable given the risk of a human rights violation. ${ }^{105}$

State parties to the ECHR, ICCPR and ACHPR, guarantee upholding the rights of piracy suspects under their effective control during the time of arrest, detention and even transfer/delivery. However, the scope of jurisdiction varies from one human rights treaty to another. For example, in Munaf $v$ Romana, the HRC observes that all that is necessary to prove jurisdiction is that the conduct which led to the violation was a "link in the causal chain". ${ }^{106}$ Therefore, the ICCPR focuses on the state's conduct and its effect - meaning a decision to transfer will make the state transferring suspected pirates liable for human rights violation, even "post-removal" of the suspects. ${ }^{107}$ This scope is similar to that of the ECHR- albeit the ECHR does not admit a cause-and-effect notion of jurisdiction like the ICCPR. ${ }^{108}$

\section{Seafarers, Crew Members and Master of a Ship - The Right to Life}

Article 4 ACHPR provides that every human being shall be entitled to respect for his life and his person's integrity. This right creates a positive obligation of state members to "deter the commission of offences against persons" 109 and updating laws and practices to conform with the international standard. ${ }^{110}$ Consequently, African states must protect persons within their jurisdiction from piracy crimes according to international standards.

Article 6 (1) ICCPR provides that "every human being has the inherent right to life" - this right shall be protected by law - and no one shall be arbitrarily deprived of his life. The right to life requires states parties to "exercise due diligence to protect individuals' lives against deprivation caused by persons or entities, whose conduct is not attributable to the

103 Petrig (n 51) 338.

104 ibid, 338-48.

105 See Soering $v$ UK App No 14038/88 (ECtHR, 7 July 1989); Al-Saadoon and Mufdhi $v$ the United Kingdom App No 61498/08 (ECtHR, 2 March 2010); See also Judge v Canada Comm No. 829/1998 UN Doc CCPR/C/78/D/829/1998 (2003) para 10; HRC, 'General Comment No 31: The Nature of the General Legal Obligations Imposed on States Parties to the Covenant' in 'Note by the Secretariat, Compilation of General Comments and Recommendations Adopted by Human Rights Treaty Bodies' (2008) UN Doc HRI/GEN/1/Rev.9, para 12.

106 Munafv Romania Comm No. 1539/2006 UN Doc CCPR/C/96/D/1539/2006 (2009) paras 14.1-14.6.

107 Petrig (n 51) 143.

108 Banković and others $v$ Belgium and 16 other States App No 52207/99 (ECtHR, 12 December 2001).

109 Communication 279/03-296/05, Sudan Human Rights Organisation \& Centre on Housing Rights and Evictions (COHRE) v Sudan, 27 May 2009, para 147.

110 General Comment No. 3 on the Right to Life, Adopted During the 57th Ordinary Session of the African Commission on Human and Peoples' Rights held from 4 to 18 November 2015 in Banjul, The Gambia. 
State". ${ }^{111}$ This means states are required to take measures that protect people's lives within their jurisdiction from all "reasonably foreseeable threats". ${ }^{112}$

Similarly, Article 2(1) ECHR provides that "everyone's right to life shall be protected by law". In Osman v United Kingdom, the Court observed that:

It must be established to its satisfaction that the authorities knew or ought to have known at the time of the existence of a real and immediate risk to the life of an identified individual or individuals from the criminal acts of a third party and that they failed to take measures within the scope of their powers which, judged reasonably, might have been expected to avoid that risk. ${ }^{113}$

The positive obligation is to protect people against reasonably expected risks from interpreting the right to life. Piracy is a "reasonably expected risk" in the GoG. Can the right to life create an obligation on states to protect seafarers, crew members and the master of a ship from deprivation to the enjoyment of their life by pirates?

On the one hand, piracy is a crime carried out on the high seas, and the flag state has exclusive jurisdiction on the high seas. ${ }^{114}$ Accordingly, the flag state has de jure jurisdiction over the ship's affairs, including the duty to protect all the crew members' rights. However, piracy is a crime of universal jurisdiction - meaning every state can exercise their de facto jurisdiction (effective control) over persons and the situation. When states initiate the counter-piracy operation, they immediately exercise effective control over persons within their jurisdiction. It is unclear whether a distress call from a vessel that has been attacked by pirates creates a jurisdictional link between the persons in distress and the state (receiving the request).

On the other hand, piracy is an outward inward situation - for instance, piracy in the GoG. ${ }^{115}$ Persons who are pirates on the high seas may be referred to as armed robbers in the territorial seas. The nature of the crime is the same, but the location differs. So, looking at Article 98 and 105 UNCLOS, it is arguable that the universal jurisdiction over the offence of piracy raises some form of obligation in protecting the lives of persons/ships at sea against pirates. Accordingly, protective measures need to be carried out throughout the navigation of a vessel. One such suggested measure is using private maritime security contractors to protect the unarmed civilians on board from pirates' whims and caprices. ${ }^{116}$ Nonetheless, the issue of human rights at sea also views the phenomenon of private maritime security contractors as a "possible insecurity factor, leading to an increased level of violence and increased insecurity of people and goods at sea." 117

The 2007 Nisour Square massacre incident provides a perspective for consideration. In this incident, a private military company (then known as Blackwater Security Consulting) contracted by the US government to protect US diplomats in Iraq was escorting a US embassy convoy, which led to the shooting of Iraqi civilians: killing 17 and

111 HRC, 'General Comment No 36 on article 6 of the International Covenant on Civil and Political Rights, on the right to life' (2018) UN Doc CCPR/C/GC/36, para 7.

112 ibid para 18.

113 Osman v United Kingdom App no 23452/94 (ECtHR, 28 October 1998) para 116.

114 UNCLOS (n 2) art 91.

115 Kamal-Deen Ali (n 7).

116 Williams and Pressly (n 14) 177.

117 Jasenko Marin et al, 'Private Maritime Security Contractors and Use of Lethal Force in Maritime Domain' in Gemma Andreone (ed), The Future of the Law of the Sea Bridging Gaps Between National, Individual and Common Interests (Springer 2017) 192. 
injuring 20 in Nisour Square, Baghdad. ${ }^{118}$ These four security guards involved in the firefight were later convicted, one of first-degree murder and the other three for manslaughter. ${ }^{119} \mathrm{In}$ sum, the Nisour Square case shows the risk these private security agents pose to life, especially if not sufficiently regulated. Borrowing from Zedner's words, "this is not to say that private security provision can never conduce to the public good but alerts us to the ways in which private security activity alters, distorts, or transforms that public good" ${ }^{20}$ Therefore, the international law regulating private security personnel needs to be further developed to clarify their roles, responsibilities and limitations.

Perhaps, the international community develops a special legal regime regulating private maritime security personnel. One can argue that Article 100 UNCLOS, which calls on all states to cooperate in the repression of piracy at sea in conjunction with the right to life, places the onus of protection on states to allow and facilitate private security services onboard. Such an argument seems plausible, but it is not conclusive because the Enrica Lexie case casts more doubts on private security safety. In that particular case, the Italian government submitted that the actions of the Indian authorities against the two Italian marines, whose duty was to authorise vessel protection detachments (VPD) onboard the Italian tanker Enrica Lexie, constituted a violation of their duty to cooperate in the repression of piracy under Article 100 UNCLOS. ${ }^{121}$ The Arbitral Tribunal unanimously held that there was no such violation. ${ }^{122}$ According to this decision, it appears that UNCLOS provisions alone are insufficient to act as a legal base to promote the protection of the right to life. Also, both parties before the International Tribunal on the Law of the Sea (ITLOS) put forward arguments on the consideration of humanity favouring their actions. There was no discussion about international human rights law, which would have given a detailed evaluation of the issue from a human rights perspective. ${ }^{123}$ Perhaps, the outcome would have been different (not absolutely) if the right to life perspective was dealt with by ITLOS. Yet again, ITLOS or the Permanent Court of Arbitration (PCA) does not explicitly deal with human rights law as a basis for its jurisdiction. The other way to go about support for onboard armed security is using the flag state principle - the flag state must ensure the protection of every person's right to life onboard a vessel flying its flag. Yet, the practice of a flag of convenience makes it difficult for a state to guarantee protection to all ships flying its flag. ${ }^{124}$

\section{Building A Sustainable Approach to Piracy at Sea}

A sustainable approach to piracy balances both right and security-based approaches. Such a view promotes the recognition of the rights of all persons under the law, i.e., the suspects, victims and state agents. Article 6 UDHR and Article 16 ICCPR provide that everyone has the right to be recognised as a person under the law. Looking at Article 16 ICCPR, the HRC has found that "intentionally removing a person from the protection of the law for a

118 Dara Lind, 'Why four Blackwater contractors were just now convicted of killing 17 Iraqi civilians in 2007' (Vox, 23 October 2014) <https://www.vox.com/2014/10/23/7047519/blackwater-trial-nisour-squaremassacre-2007-guilty-convicted> accessed 19 July 2021.

119 Dan Roberts, 'US jury convicts Blackwater guards in 2007 killing of Iraqi civilians' (The Guardian, 23 October 2014) <https://www.theguardian.com/us-news/2014/oct/22/us-jury-convicts-blackwatersecurity-guards-iraq> accessed 19 July 2021.

${ }^{120}$ Lucia Zedner, 'Too Much Security?' (2003) 31 International Journal of the Sociology of Law 155, 180.

${ }^{121}$ Enrica Lexie Case (n 50) paras 662, and 708-10.

122 ibid para 1094 (B) (1) (d).

${ }^{123}$ Enrica Lexie (Italy v India) (Provisional Measures, Order of 25 August 2015) ITLOS Reports 2015, 182.

${ }^{124}$ Flag of convenience is a practice where ships fly the flags of other States which the ship owners register under to avoid financial charges or restrictive regulations. 
prolonged period of time may constitute a refusal to recognise that person before the law." 125 Thus, not respecting the rights of every person, including piracy suspects rights, lead to more violation of human rights requirements. Therefore, Petrig argues that "the failure to perceive piracy suspects as subjects of the disposition procedure most notably in matters involving deprivation of liberty and their potential transfer for prosecutionamounts to a violation of various international individual rights with the procedural component." 126

A comprehensive approach balances sovereignty, national security, and human rights law. ${ }^{127}$ Experts in the field emphasised this need at the International Conference on Piracy in 2011 in relation to Somalian piracy, which is still relevant today. ${ }^{128}$ They mentioned the need for an innovative global tool- such as an international court with a legal mandate on piracy- to deal with national boundaries and jurisdiction constraints. ${ }^{129}$ In response to this suggestion, the Assembly of Heads of State and Government of the African Union on 27th June 2014 adopted the Protocol on Amendments to the Protocol on the Statute of the African Court of Justice and Human Rights ("Malabo Protocol"). The Malabo Protocol seeks to provide a tripartite jurisdiction over human rights, criminal and general matters within the remit of the proposed African Court of Justice and Human Rights (ACJHR). The Malabo protocol includes the crime of piracy within the jurisdiction of the ACJHR. ${ }^{130}$ However, the Malabo protocol might be rendered ineffective due to the lack of capacity to maintain the Court and African states unwillingness to sign and ratify the instrument. ${ }^{131}$

Prosecution of piracy offences is currently only at the national level, meaning joint counter-piracy operations carried out by organisations such as North Atlantic Treaty Organization (NATO) still require transfers/delivery to prosecuting states. Thus, the operational framework of the NATO mission is criticised for following a "deter and disrupt strategy and operates a catch and release scheme". ${ }^{132}$ Suppose states have no law to prosecute piracy offences. In that case, it leads to transfers during which states easily violate human rights law, making the courts question the legality of the whole maritime enforcement operation. Accordingly, another recommendation from the conference still relevant is the call for all states to fulfil their responsibility to successfully prosecute and

125 Kimouchev Algeria Comm No. 1328/2004, U.N. Doc. CCPR/C/90/D/1328/2004 (2007) para 7.8; See also Grioua v Algeria Comm No. 1327/2004, U.N. Doc. CCPR/C/90/D/1327/2004 (2007) para 7.8; See also Aouabdia v Algeria Comm No. 1780/2008, U.N Doc. CCPR/C/101/D/1780/2008 (2011) para 7.9 .

126 Petrig (n 51) 4.

127 See UNSC Res 2383 (7 November 2017) UN Doc S/RES/2383 art 33, para 11 where the Secretary General points out that "the array of threats in the region makes clear the need for a comprehensive maritime security approach, and a key priority for the international community is to secure Somalia's maritime sovereignty and suppress piracy and other threats emanating from Somalia".

128 Maximo Mejia et al, 'The Malmö Declaration: Calling for a Multi-Sectoral Response to Piracy' in Maximo Mejia et al (eds), Piracy at Sea (Springer 2013) 12.

129 ibid.

130 Protocol on Amendments to the Protocol on the Statute of the African Court of Justice and Human Rights (adopted 1 July, 2008) (Malabo Protocol) art 28A(5) < https://au.int/sites/default/files/treaties/36398treaty-0045_-

_protocol_on_amendments_to_the_protocol_on_the_statute_of_the_african_court_of_justice_and_hum an_rights_e.pdf $>$ accessed 1 September 2021.

131 Sarah Nimigan, "The Malabo Protocol, the ICC and the Idea of 'Regional Complementarity" (2019) 17 Journal of International Criminal Justice 1005, 1028-1029.

132 Petrig (n 51) 157; See also Frederick Lorenz and Laura Eshbach, 'Transfer of Suspected and Convicted Pirates' in Michael Scharf et al (eds), Prosecuting Maritime Piracy: Domestic Solutions to International Crimes (Cambridge University Press 2015) 154. 
punish the universal crime of piracy, regardless of where it is committed with due regard to international human rights law.

It is necessary to continually enhance cooperation between law enforcement and military services regionally and internationally from the operational perspective. For example, in the GoG, there should be a push for greater integration of independent and regional forces -including the basing of maritime patrol aircraft. The duty to rescue persons in distress under Article 98 UNCLOS weighs on all states and calls for a positive human rights obligation to protect persons in distress at sea. Although Article 101 UNCLOS limits piracy to an offence on the high seas and Article 92 (1) UNCLOS reserves exclusive jurisdiction on the flag state's high seas. In conjunction with the duty to cooperate to repress piracy under Article 100 UNCLOS and Article 98 UNCLOS shows that all states and institutions must curb piracy at sea. Accordingly, flag and coastal states need to fully cooperate with other industries to provide services like long-range identification and tracking details to law enforcement and promote/supervise the use of private maritime security contractors. Currently, flag states use military VPDs to protect vulnerable vessels against pirates at sea. However, there is no clear framework to regulate the use of force by VPDs yet. ${ }^{133}$ Thus, challenges remain in clarifying the roles and limitations of VPDs operating aboard vessels, including whether the master of a ship remains in control when the VPDs are onboard. For this reason, coastal states such as states in the GoG interpret the presence of armed military personnel on privately owned and operated vessels as prejudicial to the merchant vessels' status under the regime of innocent passage. Therefore, there is a need for an international framework on the embarkation and activities of VPDs, including their relationship with the master of the commercial vessel.

\section{Conclusion}

Piracy as a maritime security challenge threatens the right to life of innocent civilians at sea and therefore seemingly requires a more securitised counter-piracy approach. This is mainly because the international community has always regarded pirates as the "enemy of mankind" - hostis humani generis. ${ }^{134}$ Thus, international piracy law and state practice tilt towards a mainly repressive approach. Although the current approach has proved successful in countering piracy at sea, it still raises questions when looked at from a human rights perspective.

There are three questions observed and analysed in this paper. First, whether piracy law permitting the arrest, detention and transfer of piracy suspects has a conclusive justifiable basis under international human rights law concerning the deprivation of the right to liberty? The analysis of global, regional and domestic piracy laws shows that the legal framework is not detailed enough to fulfil the constituent elements for the deprivation of liberty at the international and regional levels. At the national level, piracy law interacts with other laws within the country. Therefore, one can only give a conclusive answer after evaluating all national laws and operational mandates tenable within the countries in the GoG, which is beyond the scope of this paper.

Another question is whether the states' positive obligation to protect civilians' lives at sea requires a higher proactiveness from states against piracy within the GoG? The obligation to protect lives applies extraterritorially to persons at sea, even on high seas, based on the de jure and de facto jurisdiction. Thus, states ought to be proactive in dealing with piracy which threatens the right to life of so many. Arguably, the use and allowance

${ }^{133}$ For more on Military VPDs, see Kiara Neri, 'The Use of Force by Military Vessel Protection Detachment' (2012) 51 Military Law and Law of War Review 73.

134 The Lotus Case (France v Turkey) (Dissenting Opinion by Judge M. Moore) PCIJ Series A No 10, 70. 
of private maritime security contractors are requirements to protect the lives at sea. These same contractors can threaten the right to life if the law does not regulate them.

The last question is whether and how counter-piracy operations can be made more sustainable rather than merely repressive? This paper illustrates why the systemic integration between international piracy law and human rights law is necessary to promote a sustainable approach to combating piracy at sea. Building a sustainable approach that focuses on human protection rather than merely repressing piracy within the GoG is necessary. This approach strikes a balance between the rights and security-based approaches to dealing with maritime security challenges such as maritime piracy. Although it is beyond this paper's scope to deduce such a framework, it offers insight into such an approach's objectives. This author suggests that further research is needed to build a sustainable counter-piracy framework. 